\title{
„Konserwatyzm - otwartość na zmiany” jako wymiar wartości różnicujący postawy wobec kultury i tradycji narodowych - raport z badań
}

\begin{abstract}
Streszczenie
W niniejszym badaniu dokonano diagnozy postaw wobec kultury i tradycji narodowych. Założono, że są one uzależnione od systemu wartości, jego zróżnicowania w wymiarze „konserwatyzm - otwartość na doświadczenie”. Badaniami objęto 368 studentów. Rozważania teoretyczne przeprowadzono na gruncie koncepcji Schwartza i wykorzystano stworzony przez tego autora Portretowy Kwestionariusz Wartości (PVQ). W diagnozie postaw posłużono się zestawem opozycyjnych przekonań na temat roli kultury i tradycji narodowych (Reykowski). Uzyskane wyniki badań potwierdziły jedną z hipotez: studenci opowiadający się za kulturowym otwarciem na Zachód cenili wyżej typy wartości wchodzące w skład „otwartości na zmiany”, tj. „kierowanie sobą w myśleniu”, „kierowanie sobą w działaniu” i „stymulacja”. Nie została potwierdzona natomiast hipoteza druga, zgodnie z którą docenienie własnego dorobku kulturowego wiąże się z akceptacją wartości „konserwatyzm”. Różnice istotne statystycznie stwierdzono w przypadku jednego konserwatywnego typu wartości, tj. „pokora”, i to tylko w jednej postawie.
\end{abstract}

1 Mirosława Czerniawska, Wydział Zarządzania, Politechnika Białostocka, Polska, e-mail: m.czerniawska@pb.edu.pl, ORCID ID: https://orcid.org/0000-0001-7311-5915. 


\title{
Słowa kluczowe:
}

postawy wobec kultury i tradycji narodowej, system wartości, konserwatyzm - otwartość na doświadczenie

\begin{abstract}
The main aim of this research is a diagnosis of attitudes to national culture and traditions. It has been assumed that attitudes depend on a system of values and variation on 'conservatism -openness to change' dimension. The sample consists of 368 students. The theoretical framework is based on the concept of Schwartz and his Portrait Values Questionnaire (PVQ) has been used. The diagnosis of attitudes is made with a set of contrasting beliefs about the role of culture and national traditions (Reykowski). The results confirms one of the stated hypothesis: students who support cultural openness towards the West, better appreciate values which constitute 'openness to change', i.e. 'self-direction-thought', 'self-direction-action', and 'stimulation'. The second hypothesis stating that the embrace of one's cultural heritage is linked with the acceptance of the value 'conservatism' is not confirmed. A statistically significant difference is ascertain according to one conservative value type, i.e. 'humility' and it is significant only for one attitude.
\end{abstract}

\section{Keywords:}

attitudes to national culture and tradition, value system, conservatism openness to change

\section{WPROWADZENIE}

W artykule Czy kultura i tradycje narodowe tracq na znaczeniu? - raport z badań porównawczych nad postawami i ich analiza w kontekście wartości (artykuł oczekuje na recenzje) zaprezentowałam wyniki badań nad zmianą postaw wobec kultury i tradycji narodowych. Diagnoza postaw była przeprowadzona w cyklu 5-letnim: w 2003, 2008 i 2013 roku. Interesowałam się również aksjologicznymi uwarunkowaniami postaw. Założyłam, że wartości kolektywistyczne wiążą się z poszanowaniem kultury i tradycji narodowych, wartości indywidualistyczne z kolei - z akceptacją przeobrażeń w warstwie kulturowej. Hipoteza ta została zweryfikowana pozytywnie. Do diagnozy wartości wykorzystałam wówczas Skalę Rokeacha (RVS). W badaniu opisanym w niniejszym artykule zastosowałam inne narzędzie, a mianowicie - adaptowany w ostatnich latach na grunt polski (Cieciuch, 2013) - Portretowy Kwestionariusz Wartości S.H. Schwartza (PVQ-R3). 
Chociaż Rokeach (1973) i Schwartz (Schwartz, Bisky 1987, 1990; szerzej na ten temat: Czerniawska, 2010a, 2010b) w podobny sposób opisywali konstrukt wartości - identyfikując je z abstrakcyjnymi pojęciami, które odnoszą się do pożądanych celów i zachowań - to zaznaczyły się różnice w sposobie interpretacji systemów wartości. Drugi z autorów kładł większy nacisk na ich organizację strukturalną. Ujął wartości w modelu kołowym (tzw. koło wartości) i zlokalizował na dwóch wymiarach:

1) konserwatyzm/zachowawczość (conservatism) - otwartość na zmiany (openness to change);

2) wzmocnienie własnego Ja / umacnianie siebie (self-enhancement) - przekroczenie własnego Ja / przekraczanie siebie (self-transcendence).

Pierwszy z wymiarów odzwierciedla konflikt między dążeniem do stabilności i kultywowaniem tradycji (submisyjne ograniczenie Ja) a dążeniem do zmian i wysokim wartościowaniem autonomii, przejawiającej się w niezależności myślenia i działania. Drugi z wymiarów odzwierciedla konflikt między koncentracją na sobie a koncentracją na innych. Koncentracja na sobie wiąże się z promowaniem własnej osoby, dążeniem do dominacji oraz ukierunkowaniem aktywności na osobisty sukces. Koncentracja na innych wymaga porzucenia egocentrycznej perspektywy, uwzględnienia dobrostanu drugiego człowieka i promowania jego dobrobytu.

W obrębie dwóch wymiarów zlokalizowane zostały określone typy wartości. Ich liczba jest zróżnicowana w zależności od modelu, który miał kilka postaci (Schwartz, 1992, 1996). Poniżej przedstawione zostaną typy wartości wyodrębnione w modelu ostatnim, wiążącym się z operacjonalizacją nowego narzędzia, tj. Portretowego Kwestionariusza Wartości (PVQ-R3) (nazwy wartości oraz ich definicje przytoczone są za: Cieciuch, 2013):

1) kierowanie sobą w myśleniu (self-direction-thought) - niezależność myślenia; wolność w poszukiwaniu i wyborze własnych idei oraz rozwijaniu własnych umiejętności; kształtowania własnego poglądu na świat;

2) kierowanie sobą w działaniu (self-direction-action) - niezależność w podejmowaniu decyzji i realizacji wybranych przez siebie celów; wolność w wyborze działań;

3) stymulacja (stimulation) - zmienność, nowość, podniecenie (opis niezmieniony);

4) hedonizm (hedonism) - przyjemność, zmysłowe zaspokojenie (opis niezmieniony);

5) osiągnięcia (achievement) - osobisty sukces osiągnięty zgodnie ze społecznymi standardami (wyeliminowano z opisu komponent kompetencji); 
6) władza nad ludźmi (power-dominance) - władza nad ludźmi, sprawowanie kontroli nad ludźmi;

7) władza nad zasobami (power-resources) - władza nad zasobami, sprawowanie kontroli nad materialnymi i społecznymi zasobami;

8) prestiż (face) - podtrzymywanie i ochrona swojego publicznego wizerunku, status społeczny, unikanie upokorzenia (typ wartości nie wyodrębniony w klasycznym modelu Schwartza);

9) bezpieczeństwo osobiste (security-personal) - bezpieczeństwo w najbliższym, bezpośrednim otoczeniu;

10) bezpieczeństwo społeczne (security-societal) - bezpieczeństwo i stabilność w społeczeństwie;

11) przystosowanie do reguł (conformity-rules) - podporządkowanie się regułom, prawu (też formalnym wymaganiom osób sprawujących władzę);

12) przystosowanie do ludzi (conformity-interpersonal) - unikanie krzywdzenia i denerwowania innych ludzi;

13) tradycja (tradition) - akceptacja i podtrzymywanie zwyczajów, idei i tradycji własnej kultury, religii lub rodziny; respekt w stosunku do tradycji;

14) pokora (humility) - uznanie małej istotności swojego miejsca w świecie i historii;

15) życzliwość-niezawodność (benevolence-dependability) - bycie niezawodnym, godnym zaufania członkiem grupy;

16) życzliwość-troskliwość (benevolence-caring) - troska o dobro innych członków grupy;

17) uniwersalizm społeczny (universalism-societal concern, universalism-concer) - dążenie do równości, sprawiedliwości i dobra wszystkich ludzi;

18) uniwersalizm ekologiczny (universalism-nature) - ochrona środowiska naturalnego, ochrona przyrody;

19) uniwersalizm-tolerancja (universalism-tolerance) - akceptacja i zrozumienie innych osób, różniących się od danej osoby.

Typy wartości 1-3 wchodzą w skład wymiaru „otwartość na zmiany”, typy wartości 9-13 w skład wymiaru „konserwatyzm”. Wymiar „wzmocnienie własnego Ja” obejmuje typy wartości 5-7, zaś wymiar „przekroczenie własnego Ja” - typy wartości 15-19. Typ wartości „hedonizm” (4) przynależy do dwóch wymiarów: „otwartość na zmiany” i „wzmocnienie własnego Ja”, typ wartości „prestiż” (8) do dwóch wymiarów: „wzmocnienie własnego Ja” i „konserwatyzm”, typ wartości „pokora” (14) - również do dwóch wymiarów: „konserwatyzm” i „przekraczanie własnego Ja”. Portretowy Kwestionariusz Wartości (PVQ-R3) różni się w stosunku do wcześniej stworzonej przez Schwartza (1996) Skali Wartości (SVS) tym, że 
pozwala na wydzielenie 19, a nie 10 typów wartości. Nowe typy stanowią jednak uszczegółowienie poprzednich.

Z punktu widzenia rozważanego w niniejszym badaniu problemu, tj. stosunku do kultury i tradycji narodowych, ważny jest wymiar „konserwatyzm - otwartość na zmiany”. Z badań międzykulturowych Schwartza wynika, że kraje Europy Środkowowschodniej w porównaniu z krajami Europy Zachodniej cenią bardziej wartości konserwatywne. Wśród krajów naszego regionu z kolei jeden z najwyższych wskaźników tego rodzaju wartości uzyskała Polska (Schwartz, Bardi, 1997, za: Lewicka, 2005, w publikacji znajduje się szersza charakterystyka zróżnicowania wartości w kategoriach wymiarów oraz typów). Wyższa preferencja wartości „konserwatyzm" wiąże się z przywiązaniem do kulturowych i religijnych obyczajów (typ wartości tradycja), powstrzymywaniem się od społecznie nieakceptowanych działań (typ wartości konformizm), troską o stabilność i ochronę społeczeństwa oraz związki z innymi ludźmi, jak również o bezpieczeństwo własnej osoby (typ wartości bezpieczeństwo). Wyższa preferencja wartości „otwartość na zmiany” skutkuje niezależnością myślenia, działania i decyzji, dążeniem do wolności, twórczości (typ wartości samosterowność), poszukiwaniem podniet, nowości, wyzwań (typ wartości stymulacja) oraz umiłowaniem przyjemności i gratyfikacji zmysłowych (typ wartości hedonizm, przynależy on częściowo do wymiaru „wzmocnienie własnego Ja”) (nazwy typów wartości pochodzą z 10-elementowego modelu, por. Schwartz, 1996).

Na wymiarze „konserwatyzm - otwartość na zmiany” (jak również wymiarze „wzmocnienie własnego Ja - przekroczenie własnego Ja”) można - jak to uczynił Schwatrz -lokalizować grupy narodowościowe i wskazać na ich kulturowe zróżnicowanie. Można też na nim lokalizować jednostki wewnątrz danej grupy narodowościowej i określić, w jakim stopniu na poziomie psychologicznym odzwierciedlają one specyfikę danej kultury. Jeżeli ludzi cechuje wyższy poziom akceptacji wartości „konserwatyzm”, to powinien ujawnić się szczególny sposób myślenia o narodzie, jego dziedzictwie kulturowym, tradycji i historii, który symuluje dążenie do zachowania tego, co już zostało „ustanowione”. Jeżeli cechuje ich natomiast wyższy poziom akceptacji wartości „otwartość na zmiany”, to ujawnić się powinny poglądy odmienne, tj. opowiadanie się za jak najszybszym przyjęciem wzorów kultury Zachodu. Założenia te poddane zostały weryfikacji w opisanym w niniejszym artykule badaniu. 


\section{PROBLEM BADAWCZY I HIPOTEZY}

Schwartz (2007) przyjął założenia modelu opracowanego przez Rokeacha (1973) odnośnie do powiązań między wartościami a postawami. Obaj autorzy uważali, że są one połączone są w sieć hierarchiczną. Priorytety w sferze wartości określają postawy, ukierunkowują ich organizację w systemie, pozwalają je przewidywać i uzasadniać, stają się również imperatywem działania. Ujawniają się w licznych (jeżeli nie we wszystkich) postawach. Niemniej jednak wartości i postawy nie są konceptualnie równoważne. Wartości są definiowane jako naczelne zasady w życiu, uporządkowane hierarchicznie ze względu na znaczenie. Mają bardziej transcendentalny charakter. Cechują się - w porównaniu z postawami - wyższym poziomem abstrakcyjności i trwałości. Postawy mają z kolei bardziej konkretny charakter i są podstawą wartościowania określonych obiektów. Siła oddziaływania ludzkich wartości decyduje o tym, jaką postawę i zachowanie jednostka wybiera spośród alternatyw, jaki wysiłek osoba wkłada w aktywność, jak długo aktywność jest kontynuowana oraz jakie reakcje emocjonalne pojawią się w przypadku sukcesu czy niepowodzenia w realizacji danej wartości (por. Czerniawska, 2010a, 2010b).

Jeżeli istnieją powiązania między wartościami a postawami, to badanie wartości powinno ułatwić przewidywanie postaw, również tych, które wyrażają stosunek wobec kultury i tradycji narodowych. Dokonując analizy znaczenia wartości ujętych w wymiarach i typach (por. model Schwartza przedstawiony wyżej), można przypuszczać, że studenci „broniący” narodowej kultury i tradycji oraz opowiadający się za odrębnością kulturową będą wyżej cenili typy wartości wchodzące w skład „konserwatyzmu”, tj. „pokora” (ten typ wartości wchodzi również w skład wymiaru „przekroczenie własnego Ja”), „tradycja”, „przystosowanie do reguł”, „przystosowanie do ludzi”, „bezpieczeństwo społeczne” i „bezpieczeństwo osobiste” (hipoteza 1). Studenci, którzy widzą konieczność dołączenia w aspekcie kulturowym do Zachodu i przyjęcia zachodnich wzorców, będą wyżej cenili typy wartości wchodzące w skład „otwartości na zmiany”, tj. „kierowanie sobą w myśleniu”, „kierowanie sobą w działaniu”, „stymulacja” i „hedonizm” (ostatni z wymienionych typów wartości przynależy częściowo do wymiaru „wzmocnienie własnego Ja”) (hipoteza 2). Najbardziej wyraźne różnice powinny ujawnić się w przypadku typów wartości: „tradycja” (co wynika z definicji tego typu) - z jednej strony, a także „kierowanie sobą w myśleniu” i „kierowanie sobą w działaniu” $-\mathrm{z}$ drugiej. 


\section{METODA BADAŃ}

Osoby badane. W badaniu wzięło udział 368 studentów pedagogiki (Uniwersytet w Białymstoku, około 50\%) i zarządzania (Politechnika Białostocka, około 50\%). Na obu kierunkach studiów około 80\% stanowiły kobiety. Wiek osób badanych zawierał się w przedziale 20-24 lata (około 90\% badanych stanowili 20- i 21-latkowie).

Narzędzia badawcze. W prezentowanym badaniu wartości były zdiagnozowane za pomocą Portretowego Kwestionariusza Wartości Schwartza (PVQ-R3), którego adaptacji na grunt polski dokonał Cieciuch (2013). W skład kwestionariusza wchodzi 57 twierdzeń (itemów). Badany ma określić (na skali 1-6), w jakim stopniu jest podobny do scharakteryzowanej w każdym twierdzeniu osoby. Na podstawie 57 oszacowań określa się wskaźniki 19 typów wartości. Wskaźnikiem preferencji danego typu wartości jest średnia uzyskana z trzech itemów. Od średniej uzyskanej dla każdego typu wartości należy odjąć średnią wszystkich (tj. 57) itemów. Uzyskuje się w ten sposób ipsatywny wskaźnik każdego z 19 typu wartości dla każdej osoby badanej. Następstwem tej procedury jest to, że część wskaźników ma znak ujemny.

Postawy były diagnozowane za pomocą dwóch par twierdzeń, które stanowią alternatywne przekonania. Zadaniem osób badanych był wybór jednej z dwóch opcji - tej, która w większym stopniu odzwierciedla poglądy jednostki w stosunku do rozważanego problemu. Twierdzenia te stanowią zmodyfikowaną treściowo wersję narzędzia zamieszczonego w pracy pod redakcją Reykowskiego (1993) Wartości i postawy Polaków a zmiany systemowe.

POSTAWA A

1. Musimy wyjść z zaścianka tradycji i naszych polskich opłotków. Polska musi jak najszybciej dołączyć do Zachodu.

2. Polska musi zostać Polską i trzeba bacznie uważać, aby importowana nowoczesność nie zniszczyła naszej kultury i tradycji narodowych, bez których nie bylibyśmy Polakami.

\section{POSTAWA B}

1. Rozpatrywanie odrębności kulturowej brzmi śmiesznie. Jeżeli chcemy, by nas poważnie traktowano, to musimy przyjąć wzorce Zachodu.

2. Poczucie odrębności kulturowej wyraża nasz szacunek do samych siebie. „Małpując” bezmyślnie innych, nie zyskamy wcale w ich oczach. 


\section{WYNIKI BADAŃ}

W niniejszym badaniu interesowano się zróżnicowaniem akceptacji typów wartości wchodzących w skład wymiar „konserwatyzm - otwartość na zmianę” w zależności od wyboru opcji postawy.

Tabela 1. Wskaźniki akceptacji wartości w grupach studentów różniących się wyborem opcji (1 lub 2) w postawach A i B oraz wyniki analizy statystycznej

\begin{tabular}{|c|c|c|c|c|c|c|c|c|c|}
\hline \multirow[t]{2}{*}{ Lp. } & \multirow[t]{2}{*}{ Wartości } & \multicolumn{4}{|c|}{ Postawa A } & \multicolumn{4}{|c|}{ Postawa B } \\
\hline & & $\overline{\mathbf{x}}_{1}=$ & $\overline{\mathbf{x}}_{2}=$ & $\mathbf{z}=$ & $\mathbf{p}=$ & $\overline{\mathbf{x}}_{1}=$ & $\overline{\mathbf{x}}_{2}=$ & $\mathbf{z}=$ & $\mathbf{p}=$ \\
\hline 1 & $\begin{array}{l}\text { kierowanie sobą } \\
\text { w myśleniu }\end{array}$ & 2,06 & 1,87 & 0,55 & n.i & 2,35 & 1,84 & 1,67 & 0,095 \\
\hline 2 & $\begin{array}{l}\text { kierowanie sobą } \\
\text { w działaniu }\end{array}$ & 0,82 & 0,31 & 1,88 & 0,061 & 1,13 & 0,35 & 1,91 & 0,057 \\
\hline 3 & stymulacja & $-0,42$ & $-1,03$ & 1,91 & 0,056 & $-0,13$ & $-0,95$ & 2,02 & 0,043 \\
\hline 4 & hedonizm & 2,89 & 2,82 & 0,43 & n.i & 3,10 & 2,78 & 0,73 & n.i \\
\hline 5 & osiągnięcia & 1,86 & 1,78 & 0,40 & n.i & 1,98 & 1,76 & 0,45 & n.i \\
\hline 6 & $\begin{array}{l}\text { władza nad } \\
\text { ludźmi }\end{array}$ & 0,89 & 1,04 & 0,11 & n.i & 0,56 & 1,09 & 1,05 & n.i \\
\hline 7 & $\begin{array}{l}\text { władza nad } \\
\text { zasobami }\end{array}$ & $-2,47$ & $-2,12$ & 0,85 & n.i & $-2,25$ & $-2,25$ & 0,01 & n.i \\
\hline 8 & prestiż & 0,95 & 1,34 & 1,12 & n.i & 1,26 & 1,18 & 0,15 & n.i \\
\hline 9 & $\begin{array}{l}\text { bezpieczeństwo } \\
\text { osobiste }\end{array}$ & 3,55 & 3,71 & 1,07 & n.i & 3,79 & 3,62 & 0,59 & n.i \\
\hline 10 & $\begin{array}{l}\text { bezpieczeństwo } \\
\text { społeczne }\end{array}$ & 3,96 & 4,20 & 1,20 & n.i & 4,09 & 4,12 & 0,18 & n.i \\
\hline 11 & $\begin{array}{l}\text { przystosowanie } \\
\text { do reguł }\end{array}$ & $-0,76$ & $-0,58$ & 0,70 & n.i & $-0,87$ & $-0,59$ & 0,74 & n.i \\
\hline 12 & $\begin{array}{l}\text { przystosowanie } \\
\text { do ludzi }\end{array}$ & $-1,43$ & $-1,20$ & 0,49 & n.i & $-1,46$ & $-1,25$ & 0,11 & n.i \\
\hline 13 & tradycja & $-1,32$ & $-1,09$ & 0,60 & n.i & $-1,75$ & $-1,05$ & 1,56 & n.i \\
\hline 14 & pokora & 0,22 & 1,41 & 3,25 & 0,001 & 0,73 & 1,04 & 0,65 & n.i \\
\hline 15 & $\begin{array}{l}\text { życzliwość- } \\
\text {-niezawodność }\end{array}$ & 0,55 & 1,14 & 2,01 & 0,045 & 0,78 & 0,95 & 0,52 & n.i \\
\hline 16 & $\begin{array}{l}\text { życzliwość- } \\
\text {-troskliwość }\end{array}$ & 1,39 & 1,58 & 0,73 & n.i & 1,64 & 1,49 & 0,38 & n.i \\
\hline 17 & $\begin{array}{l}\text { uniwersalizm } \\
\text { społeczny }\end{array}$ & 1,85 & 1,76 & 0,52 & n.i. & 2,06 & 1,72 & 1,28 & n.i \\
\hline 18 & $\begin{array}{l}\text { uniwersalizm } \\
\text { ekologiczny }\end{array}$ & $-1,41$ & $-2,82$ & 3,50 & 0,000 & $-1,65$ & $-2,49$ & 1,79 & 0,073 \\
\hline
\end{tabular}




\begin{tabular}{llllllllll}
\hline \multirow{2}{*}{ Lp. } & Wartości & \multicolumn{9}{c}{ Postawa A } & \multicolumn{7}{c}{ Postawa B } \\
\cline { 2 - 8 } & $\overline{\mathbf{x}}_{\mathbf{1}}=$ & $\overline{\mathbf{x}}_{\mathbf{2}}=$ & $\mathbf{z}=$ & $\mathbf{p}=$ & $\overline{\mathbf{x}}_{\mathbf{1}}=$ & $\overline{\mathbf{x}}_{\mathbf{2}}=$ & $\mathbf{z}=$ & $\mathbf{p}=$ \\
\hline 19 & $\begin{array}{l}\text { uniwersalizm- } \\
\text {-tolerancja }\end{array}$ & $\mathbf{- 4 , 2 1}$ & $\mathbf{- 5 , 1 3}$ & $\mathbf{2 , 1 5}$ & $\mathbf{0 , 0 3 2}$ & $-4,33$ & $-4,92$ & 0,89 & n.i. \\
\hline
\end{tabular}

POSTAWA A

1. Musimy wyjść z zaścianka tradycji i naszych polskich opłotków. Polska musi jak najszybciej dołączyć do Zachodu.

2. Polska musi zostać Polską i trzeba bacznie uważać, aby importowana nowoczesność nie zniszczyła naszej kultury i tradycji narodowych, bez których nie bylibyśmy Polakami.

\section{POSTAWA B}

1. Rozpatrywanie odrębności kulturowej brzmi śmiesznie. Jeżeli chcemy, by nas poważnie traktowano, to musimy przyjąć wzorce Zachodu.

2. Poczucie odrębności kulturowej wyraża nasz szacunek do samych siebie. „Małpując” bezmyślnie innych, nie zyskamy wcale w ich oczach.

$\overline{\mathrm{x}}_{1}$ - uśredniony wskaźnik akceptacji wartości przy wyborze opcji 1 w postawie A i B; $\overline{\mathrm{x}}_{2}$ - uśredniony wskaźnik akceptacji wartości przy wyborze opcji 2 w postawie A i B; z - wynik analizy statystycznej testem Wilcoxona dla dwóch prób niezależnych; p - poziom istotności statystycznej.

Liczba osób wybierających opcję 1 i opcję 2 w postawie A: 128 i 240

Liczba osób wybierających opcję 1 i opcję 2 w postawie B: 68 i 299

Źródło: badanie własne.

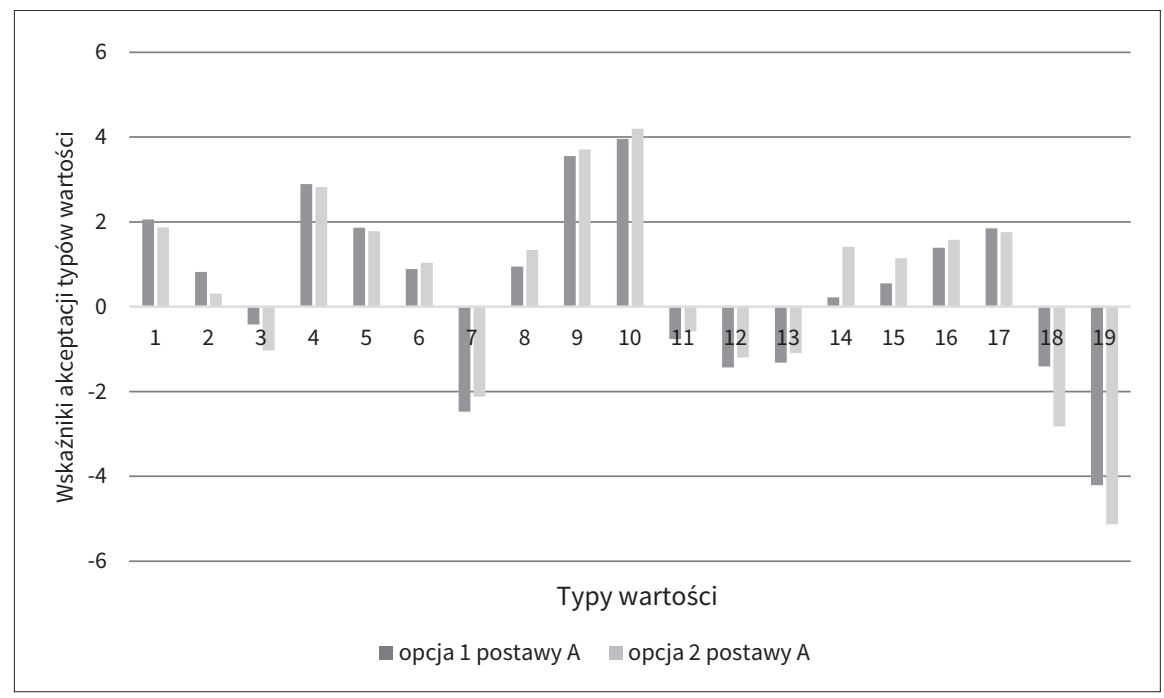

Nazwy typów wartości znajdują się w tabeli 1; w skład „otwartości na zmianę” wchodzą typy wartości 1-4 (ostatni typ - hedonizm” - częściowo); w skład „konserwatyzmu” wchodzą typy wartości 9-14 (ostatni typ - „pokora” - częściowo).

Rycina 1. Różnice w akceptacji typów wartości w zależności od wyboru opcji (1 lub 2) w postawie A

Źródło: badanie własne. 


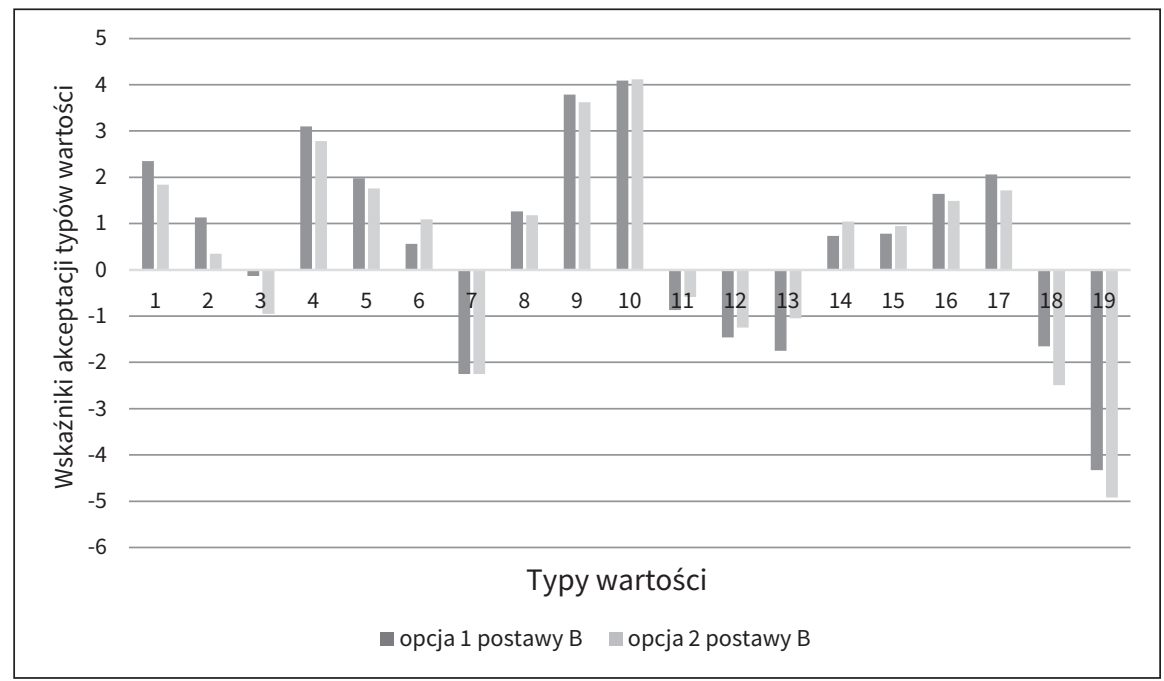

Nazwy typów wartości znajdują się w tabeli 1; w skład „otwartości na zmianę” wchodzą typy wartości 1-4 (ostatni typ - hedonizm” - częściowo); w skład „konserwatyzmu” wchodzą typy wartości 9-14 (ostatni typ - „pokora” - częściowo).

Rycina 2. Różnice w akceptacji typów wartości w zależności od wyboru opcji (1 lub 2) w postawie B

Źródło: badanie własne.

Najwyższe wskaźniki akceptacji uzyskały typy wartości: „bezpieczeństwo społeczne” (10) i „,bezpieczeństwo osobiste” (9). Zalicza się je do kategorii „konserwatyzm”. Nie stwierdzono jednak różnic w ich akceptacji w zależności od wyboru opcji w postawie A i B (por. Tab. 1, Ryc. 1 i 2).

W przypadku postawy A wyżej cenili „konserwatywny” typ wartości „pokora” (14, częściowo przynależy on do kategorii „przekroczenie własnego Ja”) ci studenci, którzy uważali, że „Polska musi zostać Polską i trzeba bacznie uważać, aby importowana nowoczesność nie zniszczyła naszej kultury i tradycji narodowych, bez których nie bylibyśmy Polakami” (opcja 2. postawy A). Typ wartości „pokora” rozumiany jest jako uznanie małej istotności swojego miejsca w świecie i historii. Pozostałe wartości zaliczane do kategorii „konserwatyzm” (tj. 9-13) uzyskiwały co prawda, wyższe wskaźniki preferencji, ale różnice nie były istotne statystycznie (por. Tab. 1, Ryc. 1). Studenci, którzy utrzymywali, że „musimy wyjść z zaścianka tradycji i naszych polskich opłotków. Polska musi jak najszybciej dołączyć do Zachodu”, cenili wyżej typy wartości wchodzące w skład kategorii „otwartość na zmiany”, tj. „kierowanie sobą w działaniu” (2) i „stymulacja” (3) (różnice na 
poziomie tendencji). Pierwsza z nich rozumiana jest jako niezależność w podejmowaniu decyzji i realizacji wybranych przez siebie celów, wolność w wyborze działań, druga jako - dążenie do zmienności, nowości i podniecenia. Typ wartości „kierowanie sobą w myśleniu” (niezależność myślenia; wolność w poszukiwaniu i wyborze własnych idei oraz rozwijaniu własnych umiejętności; kształtowania własnego poglądu na świat) był także wyżej ceniony, ale różnicy nie stwierdzono na wymaganym poziomie istotności statystycznej.

W przypadku postawy B wybór opcji 2. - „Poczucie odrębności narodowej wyraża nasz szacunek dla samego siebie, »Małpując « bezmyślnie innych, nie zyskamy wcale w ich oczach” wiązał się zazwyczaj z wyższą preferencją typów wchodzących w skład kategorii „konserwatyzm” (9-14), ale żadna z różnic nie osiągnęła wymaganego poziomu istotności statystycznej. Wybór opcji 1. w tej postawie - „Rozpatrywanie odrębności narodowej Polski brzmi śmiesznie. Jeżeli chcemy by nas poważnie traktowano, to musimy przyjąć wzorce Zachodu” dokonany został przez tych studentów, którzy wyżej cenili typy wartości „kierowanie sobą w myśleniu” (1), „kierowanie sobą w działaniu” (2) i „stymulacja” (3) (różnice w przypadku dwóch pierwszych wartości stwierdzono na poziomie tendencji, por. Tab. 1, Ryc. 2).

Ustosunkowując się do hipotez, należy zauważyć, że studenci podkreślający znaczenie narodowej kultury i tradycji (opcja 2 postawy A) oraz opowiadający się za odrębnością kulturową (opcja 2 postawy B), cenili wyżej typy wartości wchodzące w skład „konserwatyzmu”, ale różnice istotne statystycznie dotyczą tylko typu wartości „pokora” (14) w postawie A. Odnośnie do niego i tylko w tej postawie potwierdzona została hipoteza 1 . Studenci, którzy widzą konieczność dołączenia w aspekcie kulturowym do Zachodu (opcja 1 postawy A) i przyjęcia zachodnich wzorców (opcja 1 postawy B), cenili wyżej typy wartości wchodzące w skład „otwartości na zmiany”, tj. „kierowanie sobą w myśleniu” (1, tylko w postawie B) „kierowanie sobą w działaniu” (2) i „stymulacja” (3). Odnośnie do tych typów wartości potwierdzić można założenia zwerbalizowane w hipotezie 2 (przy czym część ze wskazanych różnic stwierdzona została na poziomie tendencji).

Trzeba zwrócić uwagę na typy wartości, których zróżnicowanie nie było ujęte w hipotezach. W przypadku postawy A wchodziły one w skład kategorii „przekroczenie własnego Ja”: „,̇yczliwość-niezawodność” (15), „uniwersalizm ekologiczny” (18) i „uniwersalizm-tolerancja” (19). Pierwszy z nich jest definiowany jako bycie niezawodnym, godnym zaufania członkiem grupy. Jego akceptacja ma kluczowe znaczenie w relacjach z członkami własnej grupy, w tym kulturowej. I rzeczywiście był on wyżej ceniony przez studentów przejawiających troskę o byt kultury i tradycji narodowych. Dwa następne typy wartości wyrażają dążenie 
do równości, sprawiedliwości i dobra wszystkich ludzi oraz dążenie do ochrony środowiska naturalnego. Były one cenione wyżej przez studentów otwartych na kulturę Zachodu. Należy podkreślić, że różnice w akceptacji tych wartości były największe (por. tab. 1, ryc. 1), ale jednocześnie zajmowały one najniższe pozycje w systemie. W postawie B odnotowano różnicę w akceptacji wartości „uniwersalizm ekologiczny” (18, różnica na poziomie tendencji). Miała ona ten sam kierunek, jak w postawie A (por tab. 1, ryc. 2) .

\section{WNIOSKI I DYSKUSJA}

„Konserwatyzm” i „otwartość na zmiany” opisane są jako dwie przeciwstawne kategorie wartości, które ukierunkowują „opozycyjne” poglądy na świat. W niniejszym badaniu interesowano się problemem, czy odmienne postawy wobec kultury i tradycji narodowych wiążą się ze zróżnicowaniem akceptacji wartości w tym wymiarze. Założono, że docenienie znaczenia własnego dorobku kulturowego ujawnia się u tych studentów, którzy cenią wyżej wartości „konserwatyzm” (hipoteza 1), docenienie kultury Zachodu - u tych studentów, którzy wyżej cenią wartości „otwartość na zmiany” (hipoteza 2). Założenia te zostały potwierdzone w ograniczonym zakresie. Różnice istotne statystycznie stwierdzono w przypadku jednego konserwatywnego typu wartości, tj. „pokora”, i to tylko w postawie A. Nie odnotowano natomiast istotnego zróżnicowania w akceptacji typu wartości „tradycja”, który definiowany jest jako przywiązanie do kulturowych, religijnych i rodzinnych obyczajów oraz idei, szacunek dla tradycji. Jego związek w postawami wobec rozważanej kwestii wydawał się najbardziej prawdopodobny (chociażby ze względu na nazwę tego typu wartości). W tej sytuacji należy ustalić, jakie związki ujawnią się między „tradycją” (jako typem wartości) a postawami wobec kultury i tradycji narodowych, gdy te uwzględniają inne - niż w relacjonowanym badaniu - aspekty. Może to stać się przedmiotem zainteresowań nowego projektu badawczego. Bardziej klarowne wyniki uzyskano, analizując zróżnicowanie akceptacji typów wartości wchodzących w skład „otwartości na zmiany”. Zgodnie z założeniami zwerbalizowanymi w hipotezie 2. „kierowanie sobą w myśleniu” (postawa B), „kierowanie sobą w działaniu” (postawa A i B) i „stymulacja” (postawa A i B) były wyżej cenione przez studentów opowiadających się za kulturowym otwarciem na Zachód. Były one zatem bardziej prognostyczne w przewidywaniu postaw niż konserwatywne typy wartości.

Znaczenie wartości konserwatywnych podkreślane jest w kulturach kolektywistycznych. Zawierają się one w aksjologii kolektywizmu i stanowią jej 
najważniejszą ekspresję. Akceptacja wartości konserwatywnych - jak wskazują Schwartz i Huismans (1995) - odgrywa ważną rolę: sprzyja stabilizacji porządku społecznego i integracji światopoglądu. Zredukowana zostaje wtedy złożoność ludzkiego życia i obniża niepokój egzystencjalny. Należy jednocześnie zauważyć, że konserwatyzm charakteryzuje się opozycją wobec wartości „wolność”, podczas gdy postęp opiera się na niej. Stosunek do tej wartości ma szczególne znaczenie w okresie zmian społecznych w Polsce, w których lansowany jest przez blisko 30 lat (w mniejszym lub większym stopniu) indywidualizm - typ mentalności „przystający” do liberalnej demokracji i gospodarki wolnorynkowej. W aksjologii indywidualizmu zawiera się kategoria wartości „otwartość na zmiany”, a w niej eksponowana jest przede wszystkim wolność (niezależność) w myśleniu i działaniu oraz dążenie do nowości. Uzyskane wyniki badań można więc zinterpretować w następujący sposób: jeżeli bliski mentalnie jest nam indywidualizm, przywiązani jesteśmy do wolności (niezależności) i zmian nie interpretujemy w opresyjny sposób („otwartość na zmiany”), to istnieje większe prawdopodobieństwo, że opowiadać się będziemy za kulturowym otwarciem na Zachód. Gdy jednak ustosunkowujemy się do wartości „wolność”, to warto - szczególnie z pedagogicznego punktu widzenia - wsłuchać się w słowa Arnolda „wolność to bardzo dobry wierzchowiec, pod warunkiem, że wiadomo, dokąd się jedzie” (za: Harvey, 2008, s. 14).

Akceptacja kulturowego otwarcia na Zachód wiązała się w opisywanych badaniach z wyższą akceptacją typów wartości „uniwersalizm ekologiczny” (postawa A i B) i „uniwersalizm-tolerancja” (postawa A), które przynależą do kategorii „przekroczenie własnego Ja” i wyrażają orientację społeczną (w przeciwieństwie do orientacji jednostkowej, por. Schwartz, 2007). Uniwersalizm opiera się na normie obligującej do jednakowego traktowania ludzi, bez względu na ich przynależność grupową (w tym narodowościową i kulturową). Przeciwstawiany jest on partykularyzmowi, w którym nie uwzględnia się szerszej niż własna perspektywy społecznej. Uniwersalizm - jak wskazuje Wnuk-Lipiński (1996) - wiąże się z tendencją do integracji we wspólnoty ponadpaństwowe, partykularyzm - z tendencją do zachowania państw narodowych w ich naturalnym kształcie i lokalnym tradycjonalizmem. Ta opozycja różnicuje zwolenników poglądów wobec „westernizacji” Europy postkomunistycznej. Wnuk-Lipiński rozważał ten problem ponad 20 lat temu i charakteryzował postawy polskiego społeczeństwa. W świetle uzyskanych wyników badań własnych należy stwierdzić, że stosunek do tej kwestii jest nadal zróżnicowany: 65,22\% respondentów w postawie A i 81,25\% respondentów w postawie B stało na stanowisku, że należy chronić kulturę i tradycję narodową, jako że ich cechy są nieredukowalne do cech kultur zachodnich. Przyświeca im zatem troska o to, jak nie zniszczyć poczucia narodowego „my”, które uformowane 
zostało historycznie na osnowie wspólnoty kultury, języka i terytorium. Pozostali respondenci (34,78\% w postawie A i 18,75\% w postawie B, a więc zdecydowana mniejszość) byli gotowi do przyjęcia wzorców zachodnich i identyfikacji z nimi. Ujawniają oni tym samym przekonanie, że specyficzne cechy tej kultury pozwalają efektywniej funkcjonować w „nowej” rzeczywistości. Ich troska odnosi się raczej do tego, jak budować nowoczesne państwo z europejską tożsamością i stworzyć nową definicję narodowo-kulturowej wspólnoty. Te zróżnicowane poglądy ukierunkowują dyskurs o kierunkach polityki, patriotyzmie, strategiach wychowawczych (Czerniawska, 2013), a nade wszystkim o kulturowym ideale człowieka. Czy ma być otwarty mentalnie, samodzielnie myślący i pragmatyczny, ale z rezerwą odnoszący się do tradycjonalizmu w sferze kulturowej? Czy też solidarny, zjednoczony z innymi, zobowiązany wobec członków grupy i szanujący własną kulturę i tradycję?

\section{Bibliografia}

Cieciuch, J. (2013). Pomiar wartości w zmodyfikowanym modelu Shaloma Schwartza. Psychologia Społeczna, 8, s. 22-41.

Czerniawska, M. (2010a). Zmiany wartości i postaw młodzieży w okresie przeobrażeń ustrojowych - kolektywizm versus indywidualizm. Studium interdyscyplinarne. Białystok: Wydawnictwo Politechniki Białostockiej.

Czerniawska, M. (2010b). Teorie wartości Miltona Rokeacha i Shaloma H. Schwartza. Kwartalnik Pedagogiczny, 4(218), s. 5-18.

Czerniawska, M. (2013). Patriotyzm - jak „znaleźć” mu miejsce w mentalności społeczeństwa? W: J. Nikitorowicz (red.), Patriotyzm i nacjonalizm. Ku jakiej tożsamości kulturowej? (s. 76-86). Kraków: Impuls.

Czerniawska, M. (wysłane do recenzji). Czy kultura i tradycje narodowe tracą na znaczeniu? - raport z badań porównawczych nad postawami i ich analiza w kontekście wartości. Kultura i Edukacja.

Feldman, S. (2003). Values, ideology, and the structure of political attitudes. W: D.O. Sears, L. Huddy, R. Jervis (red.), Oxford handbook of political psychology (s. 477-508). Oxford: Oxford University Press, Inc.

Harvey, D. (2008). Neoliberalizm. Historia katastrofy. Warszawa: Książka i Prasa.

Lewicka, M. (2005). „Polacy są wielkim i dumnym narodem”, czyli nasz portret (wielce) zróżnicowany. W: M. Drogosz (red.), Jak Polacy przegrywajq. Jak Polacy wygrywaja (s. 5-34). Gdańsk: GWP.

Reykowski, J. (red.). (1993). Wartości i postawy Polaków a zmiany systemowe. Szkice z psychologii politycznej. Warszawa: Wydawnictwo Instytutu Psychologii PAN.

Rokeach, M. (1973). The nature of human values. New York: Free Press.

Schwartz, S.H. (1990). Individualism-collectivism. Critique and proposed refinements. Journal of Cross-Cultural Psychology, 21(2), s. 139-157. DOI: 10.1177/0022022190212001. 
Schwartz, S.H. (1992). Universals in the content and structure of values: Theoretical advances and empirical tests in 20 countries. W: M.P. Zanna (red.), Advances in experimental social psychology (s. 1-65). Orlando, FL: Academic Press.

Schwartz, S.H. (1996). Value priorities and behavior: Applying a theory of integrated value systems. W: C. Seligman, J.M. Olson, M.P. Zanna (red.), The psychology of values: The Ontario Symposium (s. 1-24). Mahwah, New Jersey: Lawrence Erlbaum Associates, Inc.

Schwartz, S.H. (2007). Value orientations: Measurement, antecedents and consequences across nations. W: R. Jowell, C. Roberts, R. Fitzgerald, G. Eva (red.), Measuring attitudes cross-nationally - lessons from the European Social Survey (s. 161-193). London: Sage.

Schwartz, S.H., Bardi, A. (1997). Influences of adaptation to communist rule on value priorities in Eastern Europe. Political Psychology, 18(2), s. 385-410. DOI: 10.1111/0162895X.00062.

Schwartz, S.H., Bilsky, W. (1987). Toward a psychological structure of human values. Journal of Personality and Social Psychology, 53(3), s. 550-562. DOI:10.1037/00223514.53.3.550.

Schwartz, S.H., Bilsky, W. (1990). Toward a theory of the universal content and structure of values: Extensions and cross-cultural replications. Journal of Personality and Social Psychology, 58(5), s. 879-891. DOI: 10.1037/0022-3514.58.5.878.

Schwartz, S.H., Huismans, S. (1995). Value priorities and religiosity in four Western religions. Social Psychology Quarterly, 58(2), s. 88-107. DOI: 10.2307/2787148.

Wnuk-Lipiński, E. (1996). Demokratyczna rekonstrukcja. Z socjologii radykalnej zmiany społecznej. Warszawa: Wydawnictwo Naukowe PWN. 